\title{
Study of bisphenol A in sanitary landfill soil
}

\author{
N. C. Vieceli, E. R. Lovatel, E. M. Cardoso \& I. N. Filho \\ Center of Exact Sciences and Technology, Institute of Environmental \\ Sanitation, University of Caxias do Sul, Brazil
}

\begin{abstract}
The purpose of this work was the quantitative analysis of bisphenol A (BPA), in soil of two sanitary landfills in Caxias do Sul and Farroupilha, RS-Brazil. The samples were collected from closed cells and extracted by Soxhlet. The organic extracts were analyzed by Gas Chromatography with Flame Ionization Detector (GC/FID) and BPA was quantified by the internal normalization method. Standard bisphenol A (Sigma-Aldrich, 99.00\%) was used for qualitative and quantitative analysis. The average concentration of BPA was of $21.30( \pm 0.61) \mu \mathrm{g}$ $\mathrm{g}^{-1}$ of soil. The BPA concentration found in this work is much higher than the others reported in the literature. This result is worrying because there is a suspicion that bisphenol A disrupts the endocrine system.

Keywords: bisphenol A, sanitary landfill, gas chromatography.
\end{abstract}

\section{Introduction}

Around $15 \%$ (in volume) of the municipal solid wastes buried in both municipal landfills are polymeric materials. Depending on certain soil conditions, like humidity and $\mathrm{pH}$, these polymeric materials can release a relatively high quantity of organic compounds with toxicological potential called plasticizers.

Plasticizers are organic esters added to polymers to facilitate processing and to increase flexibility and toughness of the final product by internal modification of the polymer molecule. Due to their use in packaging, clothes, films, paints, adhesives, cosmetics, ink printers and many other products, plasticizers compounds are widespread in all environments. Several plasticizers were detected in mineral, ultra pure and tap waters [1], municipal solid waste compost 
[2], sewage and wastewater treatment sludge [3], river sediments [4], landfill leachate [5-7] and swine slaughterhouse wastewaters [8], among other environmental samples.

One of the main forms of exposure to plasticizers is through food, in addition to medical materials and by occupational contact [9]. Among the problems that can be caused by plasticizer compounds are: reproductive anomalies (morphological and functional gonadal dysfunction, e.g., infertility and decreased libido) and congenital malformations $[10,11]$. The plasticizers can also influence the mobility and bioavailability of toxic substances like polychlorinated biphenyls and metal ions by changes in water or lipid solubility [4].

Bisphenol A (BPA), 4,4'-(1-methylethylidene)bisphenol (CAS no ${ }^{-80-05-7) ~ i s ~}$ largely applied as a monomer in the production of polycarbonate and some epoxy resins [12]. BPA improve some physical properties of the polymeric material, like resistance, hardness, and thermal stability. The ether bonds in the polymer also increase the chemical resistance. Figure 1 shows the chemical structure of BPA.

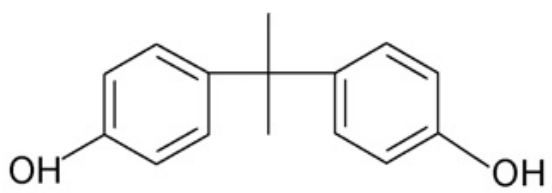

Figure 1: $\quad$ Chemical structure of BPA.

Epoxy resins are commonly employed as adhesives and cover material. The environmental persistence of BPA can be due to the low vapor pressure, moderate water solubility and partition coefficient organic carbon/water. In the environment, most of the BPA (78 to $99.3 \%$ ) is fixed in the soil. BPA can interfere in the functioning of the endocrine system, in the hormones' action mechanism. They are called endocrine deregulators or endocrine disruptors $[5$, 13]. BPA can also interfere in the action of steroid hormones inhibiting the proteins responsible for the liver metabolism [14].

In sanitary landfills, the BPA leached from the wastes is mixed with the leachate formed by the microbiological degradation of the organic content of refuse. Due to the action of rainfall, the leachate goes down through the landfill, and can contaminate the soil, surface and groundwater [15]. Typically the plasticizer concentrations in the soil are between 30 and $50 \mu \mathrm{g} \mathrm{g}^{-1}$ [4].

Despite the wide utilization and environmental relevance of BPA there is a lack of publications dealing with the study of this compound in soil. Therefore, the main objective of this work is the quantitative analysis of bisphenol A in samples of two landfill leachate soils, using Soxhlet extraction and Gas Chromatography with Flame Ionization Detector. 


\section{Materials and methods}

\subsection{Samples}

Five soil samples $(500 \mathrm{~g}$ each) were collected from the C10 cell of the São Giácomo sanitary landfill (Caxias do Sul, RS, Brazil) and one from the Farroupilha sanitary landfill (Farroupilha, RS, Brazil). Both cells were closed in 2003. The samples were collected from a depth of $2 \mathrm{~m}$ below the landfill cover in glass flasks $(500 \mathrm{~mL})$ with the cap covered by aluminum foil. The flasks were previously washed with n-hexane and distilled water and dried at $300^{\circ} \mathrm{C}$. The same purification procedures were adopted with all the glass material that had direct contact with the samples. The soil particle size was homogenized in a steel sieve with $2 \mathrm{~mm}$ mesh. The soil was stored at $4^{\circ} \mathrm{C}$, protected from light until extraction (no more than $24 \mathrm{~h}$ after collection).

\subsection{Reagents and solvents}

All the reagents and solvents were of p.a. grade and, when necessary, distilled twice in a glass apparatus.

\subsection{Physical-chemical analysis}

The main parameters tested were: $\mathrm{pH}$ (potentiometric method in humid base), moiety (gravimetry), total nitrogen (Kjeldahl and titrimetric methods), total carbon (Walkley-Black method) and phosphorous (humid digestion and colorimetry).

\subsection{Sample extraction}

After soil particle size homogenization, six soil aliquots with an average mass of $10.32 \mathrm{~g}( \pm 0.24)$ were extracted by Soxhlet in $125 \mathrm{~mL}$ of $n$-hexane by $4 \mathrm{~h}$. After this, the organic extracts were dried until constant mass and re-diluted with $n$ hexane $(1.0 \mathrm{~mL})$ and analyzed by GC/FID. Throughout the extraction process, no plastic or rubber materials were allowed to come into contact with the samples.

\subsection{Instrumental analysis}

The organic extracts were analyzed by GC/FID in a PerkinElmer chromatograph (model Autosystem) equipped with a capillary column elite plot $(30 \mathrm{~m} \times 0.25$ $\mathrm{mm} \times 0.25 \mu \mathrm{m})$. The analysis conditions are shown in Table 1 .

\subsection{Recovery grade and detection limit}

The recovery grade for BPA was measured by the extraction of a standard solution $\left(20 \mu \mathrm{g} \mathrm{mL}^{-1}\right)$. The detection limit was evaluated by the analysis of successive dilutions of a standard solution at $100 \mu \mathrm{g} \mathrm{mL}^{-1}$. 
Table 1: $\quad$ Instrumental analysis conditions.

\begin{tabular}{lc}
\hline \multicolumn{1}{c}{ Parameter } & Condition \\
\hline Initial temperature & $100^{\circ} \mathrm{C}$ (hold $\left.10 \mathrm{~min}\right)$ \\
Heating ramp & $10^{\circ} \mathrm{C} / \mathrm{min}$ \\
Final Temperature & $250^{\circ} \mathrm{C}($ hold $5 \mathrm{~min})$ \\
Carrier gas & $\mathrm{He}$ \\
Flux & $1 \mathrm{~mL} / \mathrm{min}$ \\
Injection mode & Splitless \\
Injection volume & $1 \mu \mathrm{L}$ \\
\hline
\end{tabular}

\section{Results and discussions}

The BPA was not detected in the Farroupilha sanitary landfill sample, suggesting that different residues were buried in the landfills. Thus, our discussion will be focused on the São Giacomo sanitary landfill samples.

Figure 2 shows the chromatogram of the extraction blank where no BPA peak was observed and a typical chromatogram of the real samples organic extract.

The recovery grade of BPA was $98.73 \%( \pm 4.51)$. The detection limit was $0.5 \mu \mathrm{g} \mathrm{mL}^{-1}$ and the detector response was linear between 0.5 and $25 \mu \mathrm{g} \mathrm{g} \mathrm{mL}^{-1}$

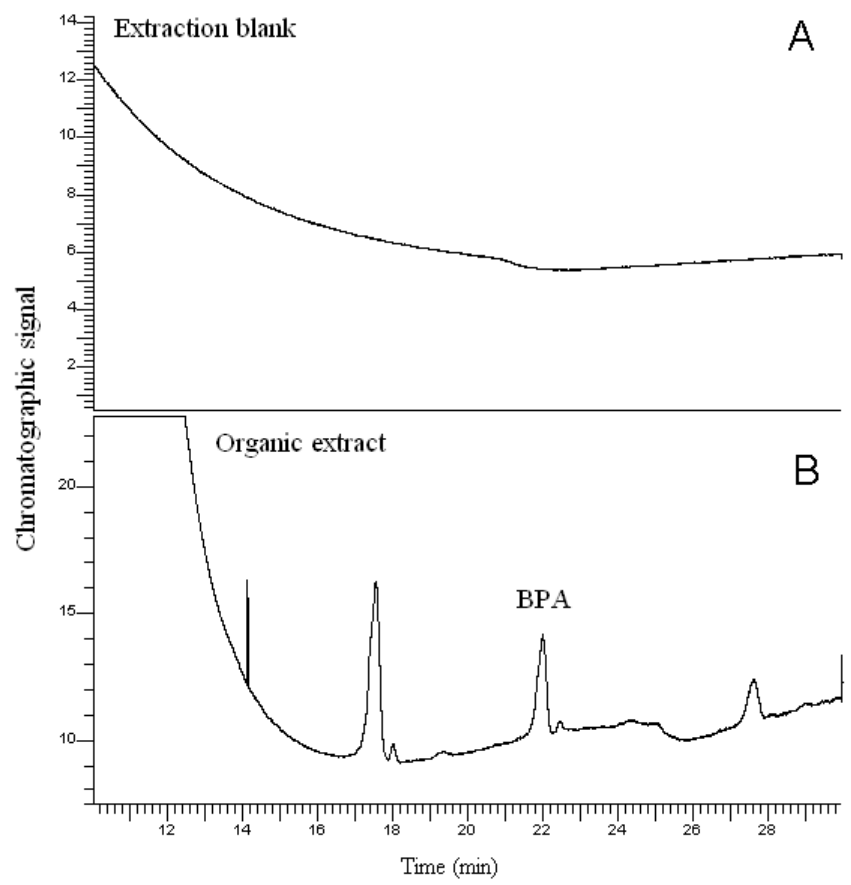

Figure 2: Chromatogram of the extraction blank (A) and the organic extract (B). 
$\left(\mathrm{R}^{2}=0.9184\right.$; equation: $\left.\mathrm{y}=3.4968 \mathrm{x}-0.3898\right)$. The average BPA concentration in the samples was $21.30( \pm 0.61) \mu \mathrm{g} \mathrm{g}^{-1}$. Yamamoto et al. [12] had reported average BPA concentrations of $0.27 \mu \mathrm{g} \mathrm{m}^{-1}$ in hazardous waste landfill samples. Thus, a landfill that receives only municipal solid wastes, like the one studied in our work can be considered much more hazardous with regard to the underground water contamination by BPA, than a typical hazardous waste landfill.

Samples of soil located outside the São Giacomo landfill (where the residues were not buried) show an average BPA concentration of $3.16( \pm 0.14) \mu \mathrm{g} \mathrm{g}^{-1}$, i.e. far below that found in the closed cells. This reinforces the hypothesis that the high concentration of BPA can be explained by the high content of polymeric material buried in the São Giácomo landfill (Figure 3). The non observance of residue segregation (into organic and inorganic categories) could be the source of the high BPA concentration.

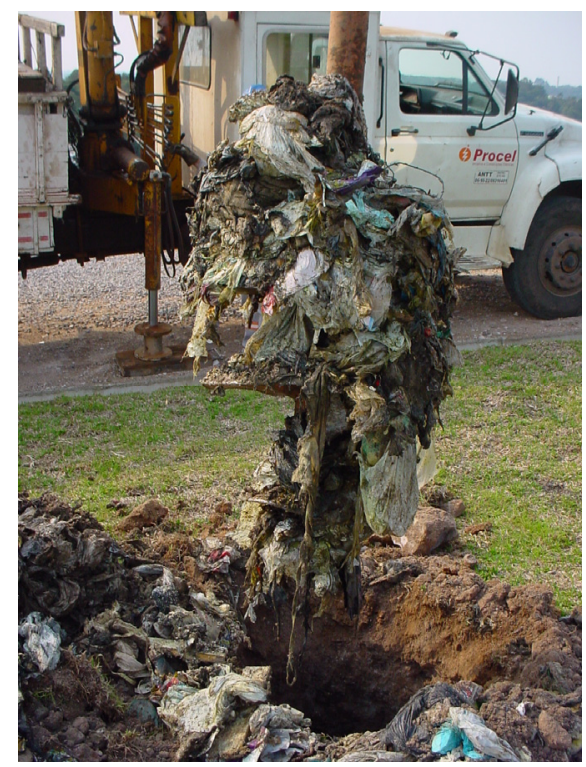

Figure 3: Polymeric material buried in the São Giácomo landfill.

The physical-chemical and microbiological characteristics of the landfill soil can enhance the release of BPA from plastic residues The results of the physicalchemical parameters (Table 2) show that both cells are in an unstable methanogenic phase [16]. In this phase the fermentation and hydrolysis of the residues generates, mainly, intermediary organic volatile acids. The leachate generated by this fermentation reduces the soil $\mathrm{pH}$. Thus, at the $\mathrm{pH}$ found for our samples (Table 2), the BPA can be poorly ionized and must be adsorbed in the organic matter. This hypothesis is reinforced by the high organic matter content of the soil samples (Table 2). 
Table 2: $\quad$ Physical-Chemical characterization of the soil samples.

\begin{tabular}{lcc}
\hline Parameter & Result & Method \\
\hline $\mathrm{pH}$ & 5.24 & Potentiometric \\
Humidity $(\%)$ & 38.7 & Gravimetric \\
Nitrogen $(\%)$ & $0 ; 3$ & Kjeldahl - Titrimetric \\
Phosphorus $(\%)$ & $<2.8$ & Humid digestion - Colorimetric \\
Organic carbon $(\%)$ & 16 & Walkley-Black \\
\hline
\end{tabular}

Therefore, the low $\mathrm{pH}$ and high organic content conditions of the soil conjugated with the presence of plastic material in the municipal solid wastes, created a favorable environment for the BPA release into the sanitary landfill.

\section{Conclusions}

The BPA concentration in the in the soil of the São Giacomo landfill is far above that found in leachate of hazardous wastes. This is a worrying result since this contaminant can migrate to the superficial and underground waters, near the sanitary landfills. BPA is a pollutant suspected of estrogen activity. It is very reasonable to assume that the sources of most of the BPA found in this sanitary landfill are non segregated domestic wastes. Therefore, it is extremely important to re-link environmental education programs focusing on the segregation of domestic wastes in inorganic, organic and recyclable categories. Likewise, the environmental laws have to be reviewed and expanded to include the plasticizers concentrations in the environment as a parameter for the soil quality and the treatment of sources of potential water pollution.

\section{Acknowledgement}

CNPq, FAPERGS, CODECA - Caxias do Sul Development Company, Jobel Engineering, Procel and Farroupilha Ambiental Inc.

\section{References}

[1] Akon, H., Yoon, B., Takayuki, K., Mariko, H., Maya, M. \& Takashi, N., Separation of endocrine disruptors from aqueous solutions by pervaporation: Dioctylphthalate and butylated hydroxytoluene in mineral water. Journal of Applied Polymer Science, 94(4), pp. 1737-1742, 2004.

[2] Gonzalez-Vila, F.J., Saiz-Jimenez, C. \& Martin, F., Identification of free organic-chemicals found in composted municipal refuse. Journal of Environmental Quality, 11, pp. 251-254, 1982.

[3] Boyd, S.A., Sommers, L.E. \& Nelson, D.W., Infrared spectra of sewage sludge fractions - evidence for an amide metal-binding site. Soil Science Society of America. 43, pp. 893-899, 1979. 
[4] Möder, M., Popp, P. \& Pawliszyn, J., Characterization of water-soluble components of slurries using solid-phase microextraction coupled to liquid chromatography mass spectrometry. Journal of Microcolumn Separation, 10(2), pp. 225-234, 1998.

[5] Bauer, M.J. \& Herrmann, R., Estimation of the environmental contamination by phthalic acid esters leaching from household wastes. Science of the Total Environment, 208 (1-2), pp. 49-57, 1997.

[6] Nascimento, I.F, von Muhlen, C., Schossler, P. \& Caramão, E.B., Estudo de compostos orgânicos em lixiviado de aterros sanitários por EFS E CG/EM. Química Nova, 24(4), pp. 554-556, 2001. Abstract in English.

[7] Nascimento, I.F., von Muhlen, C., Schossler, P. \& Caramão, E.B., Identification of some plasticizers compounds in landfill leachate. Chemosphere, 50, pp. 657-663, 2003.

[8] Aguilar, C.P., Peruzzolo, M., Di Luccio, M., Dallago, R.M. \& Nascimento, I.F., Qualitative study of organic compounds in wastewaters of a swine slaughterhouse. Environmental Monitoring and Assessment, 116, pp. 103 $110,2006$.

[9] Wams, T.J., Diethylhexylphthalate as an environmental contaminant: a review. Science of the Total Environment, 66, pp. 1-16, 1987.

[10] Nelson, P., Epidemiology, biology, and endocrine disrupters. Occupational and Environmental Medicine, 60, pp. 541-542, 2003.

[11] Mantovani, A., Problems in testing and risk assessment of endocrine disrupting chemicals with regard to developmental toxicology. Chemosphere, 39, pp. 1293-1300, 1999.

[12] Yamamoto, T.; Yasuhara, A.; Shiraishi, H. \& Nakasugi, O., Bisphenol A in hazardous landfill leachates. Chemosphere, 42, pp. 415-418, 2001.

[13] Baird, C., Environmental Chemistry, W.H. Freeman and Company: New York, 1999.

[14] Goloubkova, T.S. \& Spritzer, P. M., Xenoestrogênios: o Exemplo do Bisfenol-A. Arquivos brasileiros de Endocrinologia e Metabologia, 44, pp. 323-330, 2000. Abstract in English.

[15] Keenan, J.D., Steiner, R.L. \& Fungaroli, A.A., Landfill leachate treatment. Journal of Water Pollution Confederation, 56 (1), pp. 27-33, 1984.

[16] Rees, J.F., The fate of carbon compounds in the landfill disposal of organic matter. Journal of Chemical technology and Biotechnology, 30, pp. 161175.1980 . 